\title{
Improving Students English Vocabulary by Using Tic Tact Toe Game at The second Year of SMP Negeri 7 Satap Maiwa Kabupaten Enrekang
}

\author{
HASAN
}

\section{STKIP Muhmammadiyah Enrekang, Indonesia}

Email: hasan@ummaspul.ac.id

\begin{abstract}
This research was intended to explain the students English vocabulary by using Tic Tact Toe game at the second year of SMP Negeri 7 Satap Maiwa in the 2016/2017 academic year. In this research used quasy experimental class. It had conducted in two groups namely experimental group and control group. The population in this research were students in class VIII involved 30 students. The researcher took real data from the class to know the students English vocabulary. the instruments of this research were pre-test and post-test with multiple choice. From these findings, there was significance improvement of the students English vocabulary by using Tic Tact Toe game.
\end{abstract}

Key Words: English Vocabulary, Tic Tact Toe Game, Vocabulary Mastery

\section{INTRODUCTION}

Vocabulary skill is one of linguistic features, which influences the communicative competence. Paulston et al (1976: 55) state that the one thing that interferes most with our students' communicative competence is pitiable vocabulary and we have recently come to accept the fact that our students have been right all these years when they complained about not knowing and not being taught sufficient words.

The above statement reveals that vocabulary skill is very important but students are very weak in it. Furthermore, Hammer (1991: 23) assets that for many years that vocabulary was seen as supplementary to the main purpose of language teaching, namely the acquisition of grammatical knowledge about the language. Vocabulary was necessary to give student something to suspend on learning structures, but was frequently not a main focus for learning itself. Words are basic structure blocks of language; in fact survival level of communication can take quite comprehensibly when people simply link words together without any grammatical rules applied at all. So if we interested in being communicative, words are among the first order of business.

In line with the above statement Carter and Nunan (2001: 42) write the English teachers learn to ignore the significance of vocabulary in their teaching of speaking or communication 
performance. In fact the use of suitable vocabulary.

In learning English, many students face difficulties to express their ideas, minds, feelings, and experience because they sometimes lose their words to say or to write. They also miss some information when they read or listen something because they do not understand the meaning of those words. This is importance of mastery vocabulary. When they mastery vocabulary, it will be easy for them to master four skill of language that is reading, speaking, listening and writing (Wahyuni, 2004).

Learning vocabulary as a foreign language seems easy but some students feel fear. The teacher of English should fine out by created an efficient and effective technique in teaching vocabulary, beside that, the teacher should establish condition which makes teaching vocabulary possible.

According of the competence based on curriculum of junior high school, the goal of foreign language learning is to learn how to communicate by using target language orally or written. So after learning English, the students should be able to communicative in English spoken or written.

The function of learning English in junior high school are; first, by studying English students are expected to have a means to develop their knowledge of science, technology, and culture. The second is students are expected to be able to support the development and tourism.

The acquisition an educating vocabulary is essential for succesfull second language because without an extensive we will be unable to use structure and function. Of course, the vocabulary mentioned here is the vocabulary in curriculum of junior high school.

Students must be able to use a lot of vocabulary in English, if they want to be successful in learning. Vocabulary is an important element language besides pronunciation and grammar. We can not express ideas in English without learning English vocabulary. So that, when students are given a passage with word that is supposed have been taught earlier, they still find it difficult to understand the meaning.

Realizing how the important the vocabulary to build up the teachers of English have provided students with rich exciting exercise which are expected to help vocabulary which must be very helpful to improve ability in English communication. To make students motivate and enjoyable to study vocabulary, the researcher should be creatively in delivering material. We should use varieties strategies in teaching vocabulary.

One of strategies that can be used by teacher is using media to support the teaching learning process. There are some teaching media available now, so the researcher used games to improve students' vocabulary. The outcome of this study is expected to be useful to helpful information for the English lecturer in general in order to increase the students' vocabulary by using Tic Tact Toe game. The research question: is the use of Tic Tact Toe game improve students' English vocabulary?

\section{LITERATURE REVIEW}

Ramiani (2010) in her study "Assessing Vocabulary Mastery through Pictures and Sentences Matching of The Seventh Grade Students of SMP Widya Sakti Penatih in Academic Year 2009-2010". Here she stated that the use of pictures and sentences matching is a technique to improve student's ability in mastering vocabulary. The method that was used in her research is observation research 
by taking the data only in one meeting. We have to do more research because it is an observation research.

Putrawan (2008) in his study "Teaching Vocabulary through Total Physical Response (TPR) technique to the fourth Grade Student of SD no. 4 Ubud "tegallantang" in academic year 2007-2008 the data source in this research was the fourth grade students bof SD No. 4 Ubud Tegallantang which consists of 22 students altogether in class. In this research, he wants to find out the effectiveness of TPR in improving the students' ability in memorizing vocabulary. He stated that the use TPR has a big effect in teaching vocabulary. The lack of this study is the students often find difficulty in expressing the word in to the proper action.

Wiyanjani (2009), in title "Teaching Vocabulary through Cooperative Learning with Puzzle Technique to the Eight Grade Students of SMP Negeri 2 Sidemen Academic Year 2008/2009". In this paper she explained the learning process of vocabulary through cooperative learning with puzzle technique which encourage the students to find the words as many as they can diagonally horizontally and vertically.

Wahyuni (2004) in her research "improving students" vocabulary mastery through related words game " found that vocabulary of the second year students of SMPN 1 Sinjai Selatan increased. It is proved by the students posttest, the mean score (7.36) is higher than mean score of the students in pretest $(5,14)$. In other words, the related word game is effective to improve the students' vocabulary.

Kasim, Nur aeni (2011) in her research 'Increasing the students' vocabulary Mastery by using world wall media" concludes that implementation of word wall media in teaching vocabulary could make the students active in learning process.

Sakkir, Geminastiti (2004) The students' vocabulary mastery of the second years of SMP Kemala Bhayangkari Ujung Pandang through specific word game. She conclude that there are achievement vocabulary student were taught specific word game.

\section{The concept of Vocabulary}

\section{a. Definition of vocabulary}

The definition of vocabulary is taken from many sources as follows:

According to Penny (1991:60) Vocabulary can be defined, roughly, as the words we teach in the foreign language

According to Barnhart (2008:697)

1) Stock of words used by person, class of people, profession, etc.

2) Collection or list of words, usually in alphabetical order and defined."

According to on line-Webster dictionary

a list or collection of words or of words and phrases usually alphabetically arranged and explained or defined: lexicon $a$ : a sum or stock of words employed by a language, group, individual, or work or in a field of knowledge $b$ : a list or collection of terms or codes available for use (as in an indexing system) a supply of expressive techniques or devices (as of an art form)

According to Hornby $(1989: 1425)$ is vocabulary is body of words known to a person in particular book subject. Vocabulary is the total number of words that make up language. Vocabulary is list of word with their meaning, 
especially one with accompanies a text book in foreign language.

According to Good vocabulary is the context a function words of language which are learned so thoroughly that become a part understanding, speaking and later reading and writing

Urdang and Flexner (1986) define vocabulary as the stock of the words used by or known to a particular person or group person, a list of collection the words or phrase of a language.

Said (1992) points out that vocabulary is one of the important aspects in mastering English because the ability of the students to read and to comprehend the subject is relatively determined by their vocabulary

Based on the definition above, the researcher concludes that vocabulary is a total number of words and phrase of a language, with their meanings, definitions or translations and usually arranged in alphabetical order.

\section{b. Types Vocabulary}

Words in a language are small elements, which could make up a language and function to express ideas. Linguistics classifies vocabulary in to two kinds:

1) Receptive vocabulary refers to the words or lexical items, which can be recognized and comprehended in context of listening and reading

2) Productive vocabulary refers to words, which we use in speaking and writing.

Table 2.1 Productive Vocabulary

\begin{tabular}{ccc}
\hline Process & Oral & Written \\
\hline Receptive & Listening & Reading \\
\hline
\end{tabular}

Productive Speaking Writing

Harmer (1991:159) divides

vocabulary into two types, they are:

1) Active vocabulary refers to vocabulary that students have learned

2) Passive vocabulary refers to the words which students will recognize when they meet them but they will probably not be able to produce.

Good (1959:644) divides

vocabulary into four kinds:

1) Oral vocabulary refers to words which a person employs them in expressing ideas orally and actively.

2) Writing vocabulary refers to words which commonly used in writing

3) Listening vocabulary refers to words which a person can understand when they heard

4) Reading vocabulary refers to words, which someone can recognize them when he finds them in written form.

\section{c. The techniques teaching vocabulary}

Teaching and learning vocabulary is not simple. The teachers' ability to recognize the students' competence and characteristic is needed. Teaching vocabulary to children is not the same as to boys and girls, so the material taught to the students should be suitable with their level or ages. Harmer (1991:7) classifies the level of the students as children, adolescent beginners, and adult intermediate and adult advanced students.

Gairn's and Redman (1986) suggest the following types of vocabulary presentation techniques:

1) Visual techniques. These pertain to visual memory, which considered especially helpful with vocabulary retention. Learns remember better the material that has been presented by means of visual aids. Visual techniques lend themselves well to 
presenting concrete items of vocabulary nouns; many are also helpful in conveying meanings of verbs and adjectives. They helpful the students associate presented material in a meaningful way and incorporate it into their system of language values.

2) Verbal explanation. This pertains to the use of illustrative situation, synonymy, opposites, scales, definition and categories, and use of dictionaries. Using a dictionary is another technique of finding out meaning of unfamiliar words and expressions. Students can make use of variety of dictionaries: bilingual, monolingual, pictorial, thesauri and the like. As French perceives them, dictionaries are "passports to independence" and using them is one of the students centered learning activities (1983:83)

\section{d. The acqusition of vocabulary}

In recent years, second language vocabulary acquisition has become an increasingly interesting topic of discussions for researchers, teachers, curriculum designers, theory and other involved in second language learning. Vocabulary has long had synergistic association with reading, each activity nourishes the other. According to Laufer (in Coady and Huskiness book) there are three serious problems that may seriously impede reading comprehension in second language acquisition. First, the problem of insufficient vocabulary, the second is misinterpretations of deceptively transparent words and the last is inability to guess unknown words correctly. She claimed that by far the greatest lexical factor in a good reading is the number of the words in the learnerse ${ }^{\text {ee }}$ lexicon. A vocabulary of 3000 word families or 5000 lexical items is needed for general reading comprehension, as this would cover 9095\% of any text. Below this threshold, reading strategies become ineffective.

A large vocabulary is also claimed to solve the other two problems: deceptive transparency and guessing ability. Deceptive transparent words are the words that look familiar to the learner even though they are they are unfamiliar. These are words with deceptive morphological structure (e.g. nevertheless $=$ never less), idiom false friend, words with multiple meaning and conforms (cute / acute). Laufer argues that missing interpretation of such words are widespread among second language learner. Guessing words meaning by use of contextual clue is far more difficult, according to Laufer than is generally realized. Can be impaired any of the following factors, nonexistence of clues, lack of familiarly with the word in which the clues are located, presence misleading and incompatibility between the reader schemata and the text content.

Methodologist and linguistics have increasingly been turning their attention to vocabulary, stressing their importance in language teaching and reassessing some of the ways it is taught and learn it means that vocabulary plays a very important role in language teaching. As the objective of language is to cultivate student's skill, namely listening skill, speaking skill, reading skill and writing skill. The acquisition of meaning also influences the performance of students on those skills. The acquisition of meaning here is considered as the readers prior knowledge and learning (Carter and Nunan, 2001:44)

\section{e. The Kinds of vocabulary}

The characteristic of the words meaning of a word not in term of it is component features, but in term of its 
relationship to other word is treated as the analysis of lexical relation (Yule:2010). The types of lexical relation which are usually appealed to can be briefly defined and exemplified those:

1) Synonymy. Synonymy is a word which has the same or nearly the same meaning as another word (Richard et al, 1985:7). Thus synonymy are two or more forms with very closely related meaning, which are often but not always, intersubstitutable in sentences. Example of synonyms is the pairs: applaud-cheer, brief short, bold brave.

2) Antonym. Antonym is a word which is opposite in meaning to other word. Hence, two forms opposite meaning are called antonyms. Antonyms are further distinguished into two types via, gradable and non-gradable antonyms. The pairs bad-good and dry-wet are examples of the gradable and non-gradable antonym respectively. A thing is not bad must be good, but the season which is not wet must be dry.

3) Hyponymy. Hyponymy is the relationship between two words, in which the meaning of one words includes the meaning of the other. Typical examples of such pairs are: dog-animal, carrot-vegetable. The concept of inclusion involved here is the idea that if any object is a dog, it is necessarily an animal. So, the animal is included in the meaning of $\mathrm{dog}$, or dog is hyponym of animal.

4) Homophony. Homophony is used to describe the relationship between two more different forms (written) which have the same pronunciation like the pairs: die-dye, curb-verb, key-quay, fore-four, and gait-gate.

5) Homonymy. The term homonymy is used when one form (written or spoken) has two or more unrelated meaning. Examples of homonyms are the pairs: lead (first place of position) - lead (of water pipes), sow (adult female pig) - sow (plant).

6) Polysemy. Polysemy is defined as one form (written or spoken) having multiple meaning which are all related by extension (Richard et al, 1985: 15). Polysemy is a property of a single lexeme (Lyons, 1984:67).

\section{$f$. The Advantage using games}

There are many reasons why the teacher use games in student's classroom, but actually the important things that the teachers often use games because games have many advantages for both the teachers and the students.

Richard-Amanto (1998) states that there are many advantages to use game. Games can lower anxiety, thus making the acquisition or input more likely. They are highly motivating and entertaining, and they can give shy students more opportunity to express their opinion and feelings. They also enable learners to acquire new experiences within a foreign language which are not always possible a typical lesson.

According to Salaka (2006), the advantages of using games are:

1) Having games in the classroom is help to break up the tedium of learning the language.

2) Providing a game in the classroom transforms the mostly material centric pedagogy into a more student's centric lesson, this helps to not only reinforce the material through active practice, but it serves to make up the material meaningful for the student which helps them to retain and regurgitate the language better.

3) Games help to break down student's reliance on textbook formulation, and in turn, allow them to 
incorporate the language into their own language patterns.

4) Games allow the material previously studied to be reviewed and not overwhelm the students with more material they can currently handle.

5) Games provide a completely students centric activity where the teacher serves only as facilitator and provides opportunity for all students in the class to participate. We can conclude that games are useful for the students and the teacher as well, especially because games can provide intermediate for the teacher. Nevertheless, some games are, of course, more suitable for the children and other for adults, thus teacher should choose which is suitable.

g. The concept of Tic Tact Toe game in teaching

The rule of Tic Tact Toe Vocabulary is:

1) Draw a tic tact grid on the board

$\begin{array}{lll}1 & 2 & 3 \\ 4 & 5 & 6 \\ 7 & 8 & 9\end{array}$

Write nine words that will become the answers of the tic tact grid on the board. For example:

$\begin{array}{lll}\text { Policeman } & \text { gardener } & \text { custodian } \\ \text { Nurse } & \text { chef } & \text { dancer } \\ \text { Doctor } & \text { singer } & \text { farmer }\end{array}$

2) Divide the students into two groups. Give each team a mark. Group $A=X$, group $\mathrm{B}=\mathrm{O}$.

Ask the students to memorize the nine words in five minutes, and then erase the nine words slowly.

a. Ask the student about the question that the answer is one on the words that already erased on the board. If the answer is correct, the team gets to put its mark in that space.
Teacher: a person who takes care a patient is a.....

0 team: nurse

b. The first to mark out there boxes in a straight line, vertically, horizontally, or diagonally win the game.

\section{Research Design}

This research would apply quasy experimental design. This research would two kinds of variable namely dependent variable and independent variable. The researcher would use a test as instrument in collecting data. They are pre-test and post-test

\section{FINDING AND DISCUSSION}

The description of the collected data through the test as explained in the previous section showed that the students' vocabulary achievement was improved after the treatment by using Tic Tact Toe game especially for experimental group. It was proved by the mean score of post-test for experimental group was higher than the mean score of pretest for experimental group (16.5333 >15.5333) although both of them in good level. The posttest score of experimental group also showed that there was students' vocabulary achievement.

Besides that, based on the data in previous section, the students' vocabulary achievement in experimental group and control group after the treatment is significantly different, where the students who used Tic Tact Toe game had higher score than the students in control group who did not use Tic Tact Toe game in vocabulary. It was supported by the difference between the mean score of post-test in experimental group (16.5333) was higher than the control group (14.4667).

This research data indicated that the use of Tic Tact Toe game improved 
students' vocabulary achievement. Even though both using Tic Tact Toe game and conventional technique (without Tic Tact Toe game) could improve the students' vocabulary achievement, however, the use of Tic Tact Toe game in vocabulary process gave better effect than the use of conventional technique. This result goes in line with what Lewis in Wijayani (2009:15) stated that vocabulary should be at the center of language, teaching, because language consist of gramaticallized, lexis, not lexicalized grammar. Teaching vocabulary should be part of the syllabus and taught in a well planned and regular basis. it support the statement of Madsen (1983:12) stated that the purpose of vocabulary test is to measure the comprehension and production of words used in speaking and writing. Furthermore, the result of the research also supports the statement of RichardArmanto (1998) states that there are many advantages to using games. Games can lower anxiety, thus making the acquisition or input more likely, they are highly motivating and entertaining and they can give shy students more opportunity to express their opinion and feelings.

Based on the statistic test in asymptotic significant (2-tailed) column, in pretest of experimental group and control group, the researcher found that the probability values was higher than alpha $(\alpha)(0.000>0.05)$ which means that there was no significant difference in pre test between experimental group and control group. While on statistic posttest result for both groups. It showed that the probability value is higher than alpha $(\alpha)(0.000>0.05)$. It means that $\mathrm{H} 1$ was accepted and H0 was rejected. It is concluded that there was significance difference between students' vocabulary achievement who used Tic Tact Toe game and whom did not use Tic Tact Toe game (conventional technique). In order words, there was an improvement on the vocabulary achievement after using Tic Tact Toe game in the second years at SMP Negeri 7 Satap Maiwa Kabupaten Enrekang.

\section{CONCLUSION}

Based on the findings and discussions, the students' vocabulary achievement between who used Tic Tact Toe game and those who did not use Tic Tact Toe game had significant difference. The researcher found that the t-test value was higher than t-table (9.186>2.021). It means that H0 was rejected and $\mathrm{H} 1$ was accepted. There are three kinds of vocabulary test such as complete the words, translate the words and multiple choice. Therefore, the researcher puts forward conclusion that the use of Tic Tact Toe game improves the students' vocabulary achievement in the second years at SMP Negeri 7 Satap Maiwa Kabupaten Enrekang.

\section{REFERENCES:}

[1] Arikunto. 2006. Petunjuk Teknis Penulisan Karya Tulis Ilmiah. Jakarta. Gudang Ilmu.

[2] Barnhart.2008. Increasing Vocabulary.

Online.Http//:www.Concept of vocabulary.co.id. Accessed on 23 March 2017.

[3] Carter \& Nunan.2001. Teaching Vocabulary With Games. Online.Http//:www.teaching Vocabulary.co.id. Accessed on 23 March 2017.

[4] Depdiknas. 2006. Petunjuk Pelaksanaan Praktek Belajar Mengajar dan Petunjuk Pelaksanaan Sistem Penilaian. Jakarta. Depdiknas. 
[5] Good. 1993. Dictionary of Education. New York. MC Grow Hill Book Company

[6] Good. 1959. Dictionary of Education. New York. MC Grow Hill Book Company.

[7] Gairnrs \& Redman.Teaching Vocabulary With Games. Online. Http//:www. Definition of Vocabulary.com. Accessed on 5 June 2017.

[8] Gay, L.R. 2006. Educational Research. Competencies for Analysis and application.Meril Publishing Company A Bell and Howell Information Company Columbus.

[9] Hammer. 1991. The Practise of English Language Teaching. New edition. London: Longman.

[10] Horrnby.1989. Advance Learner's Dictionary of Current English Hand Book for Language Teacher. London: Longman.

[11] Kroehnert. 1997. Teaching Vocabulary. Online. Http//:www. Teaching Vocabulary.co.id. Acessed on 23 April 2017.

[12] Kasim, Nur aeni. 2011. Increasing the Students' Vocabulary Mastery by Using World Wall Media. Skripsi.

[13] Lewis \& Wijayani. 2009. Kinds of Vocabulary. Online. Http//:www. Teaching Vocabulary.co.id. Accessed on 23 April 2017.

[14] Lyons. 1984. Word Power 3000. Tokyo City: Oxford University Press.

[15] Madsen. 1983. The Principles of Teaching In English. Online. Http//:www. Teaching Vocabulary.co.id. accessed on 23 April 2017.

[16] Murchia \& Olshtain. 2007. The Principles of Vocabulary. Online. Http//:www. Vocabulary.co.id. Accessed on 5 May 2017.

[17] Paultson, et al. 1976. Technique and Teaching Vocabulary. Tokyo City: Oxford University Press.
[18] Putrawan. 2008. Teaching Vocabulary through Cooperative Learning with Total Physical response (TPR). Skripsi: Tegallantang.

[19] Penny. 1991. Dictionary Online Webster.

[20] Pikulski \& Templeton. 2004. Teaching and Learning Vocabulary. Boston: Victoria University of Wellington.

[21] Ramiani. 2010. Assesing Vocabulary Mastery through Pictures and Sentences Matching of The Seventh Grade at SMP Widya Sakti Penati. Skripsi.

[22] Richard, et al. 1985. Acqusition Vocabulary. Online.

Http//:www.Teaching

Vocabulary.Co.Id. Accessed on 2 April 2017.

[23] Richard, Amanto. 1998. Increasing Vocabulary Through Anecdot. Online. Http//:www.Teaching

Vocabulary.co.id. Accessed on 23 April 2017.

[24] Redman. 2001. Fluenty Speaking by Mastery Vocabulary. Online. Http//:www.teaching Vocabulary.co.id. Accessed on 23 April 2017.

[25] Sakkir, Geminastiti. 2004. The Students' Vocabulary Mastery of the Second Years of SMP Kemala Bayangkari Ujung Pandang Through Specific Word game. Skripsi.

[26] Salaka. 2006. Tik Tack Toe Game Teaching Approaches. Online. Http//:www. Types of games.co.id. Accessed on 9 June 2017.

[27] Sunarti. 2002. Types of Games. Online. Http//:www. Types of games.co.id. Accessed on 9 June 2017.

[28] Said. 1992. English For Senior secondary school. Jilid 1. Bandung: Grafindo Media Pratama.

[29] Sugiono. 2007. Panduan Penulisan Karya Tulis Ilmiah. Jakarta: Rineke Jaya. 
[30] Urdang \& Flexner. Learning Vocabulary. Online. Http//:www. Definition of Vocabulary.co.id. Accessed on 9 June 2017.

[31] Wahyuni. 2008. Improving Students' Vocabulary Mastery through Related Word Game at the Second years at SMP Negeri 1 Sinjai Selatan . Skripsi.
[32] Wijayani. 2009. Teaching Vocabulary through Cooperative Learning With Puzzle Technique to Eight Grade at SMP Negeri 2 Sidemen. Skripsi.

[33] Yuliana. 2004. Script Skripsi. Online. Http//:www. Kumpulan Skripsi.com. Accessed on 23 March 2017. 